\title{
Scientific work and problem-solving in health care management: a way for the practitioner?
}

Bernhard Schaller

University of Oradea, Romania

Submitted: 3 April 2011

Accepted: 31 August 2011

Arch Med Sci 2012; 8, 5: 817-818

DOI: 10.5114/aoms.2012.31615

Copyright $\odot 2012$ Termedia \& Banach

Scientific work is on the one hand an art, in which some are more talented than others. But on the other hand science has also a certain learning curve. Manuscripts are always influenced not only by academic interests and knowledge, but also by extracurricular activities and life experiences. This is one of the principal reasons why great institutions, like for example the Max Planck Society, have a lot of physicians working in clinically orientated medical research. All these different factors have a great impact on the motivation to write a scientific text [1], as the authors can include their own (clinical) experience in their scientific manuscripts. Such a process is called "problematization" and means critical thinking about the scientific results in the context of personal experience and arriving at new viewpoints. This mechanism also explains the "learning curve". However, the most important skill for scientific writing seems to be the creativity that is influenced by cognitive abilities, personal characteristics, and also social factors [2].

But what does this mean in the daily business practice of our hospitals or health care institutions? Healthcare business management is nowadays very demanding [3] and persons having double university degrees are more and more required at an executive level, also at university hospital. The need for business administrative and clinical knowledge for decision makers is obvious [3], but little is known about the specific management tools in the health care system, as most of the theory of them is derived directly from industry [4]. This would open the window for scientifically interested practitioners to add new management papers to the literature. The creative potential that comes from this scientific approach, combined with the personal daily practical aspects, represents a great potential for the university, but also the scientific community, to create new health care adapted management models and theories $[5,6]$. This is in line with the opinion of Arthur Schawlow, winner of the Nobel prize in physics, 1981, who said that "the most successful scientists often are not the most talented. But they are the ones who are impelled by curiosity [7]". New knowledge in business administration in our times, especially in the health care field, is based on the curiosity of the practitioner to understand the things that they see in daily practice of health care management better and more precisely [8]. The importance of this curiosity for scientific success also emphasizes the previously nearly neglected social factors affecting creativity that are influenced by the life experience and that can provide a comprehensive view of the scientific performance [2].
Corresponding author:

Prof. Bernhard Schaller University of Oradea 410087 Oradea

Romania

Phone: +40259408113

Fax: +40 259432830 
Modern health care management takes place in organizations and institutions that are becoming more and more complex. The management of these institutions requires broad clinical and business administrative knowledge, but also excellent scientific skills. Scientific skills are important for the reason that such a leader can perform a good problematization process. The success of his institution will depend on this ability. From this point of view, persons with double academic degrees and a scientific background have the best prerequisites to substantially influence the university but also the scientific community. It is also for that reason that we should educate our scholars in scientific principles. It is more important than ever!

\section{References}

1. Hayes JR, Indrisano R, Squire JR (eds). Perspectives on writing. Research, theory, and practice. Newark, DE, US. International Reading Assocaiton 2000; 6-44.

2. Amabile TM. The social psychology of creativity. A componential conceptualization. J Pers Soc Psychol 1983; 45: 357-76.

3. Mettler T, Rohner P. Performance management in health care: the past, the present, and the future. In: Hansen $\mathrm{HH}$, Karagiannis D, Fill HG (ed). Österreichische Computer Gesellschaft. 9. Internationale Tagung Wirtschaftsinformatik. Wien, Austria, 2009; 699-708.

4. Laffel G, Blumenthal D. The case for using industrial quality management science in health care organizations. JAMA 1989; 262: 2869-73.

5. Schaller B. Educational attainment and risk of stroke and myocardial infarction. Med Sci Monit 2003; 9: LE27.

6. Schaller B. Medical education and the Bologna process. Arch Med Sci 2007; 3: 3-4.

7. "Going for the Gaps". Interview in The Stanford Magazine. 1982; 42.

8. Schaller B, Sandu N. Clinical medicine, public health and ecological health: a new basis for education and prevention? Arch Med Sci 2011; 7: 541-5. 